\title{
The Influence of Dry Port Establishment on Regional Development Through Regional Development Index
}

\author{
Ivica Lovrića , Dajana Bartulovićb, Sanja Steiner ${ }^{c}$
}

The goal of the Regional Development Policy of the Republic of Croatia is to contribute to the identification of priority activities that would strengthen the development potential of all Croatian regions, reduce regional disparities, strengthen and build the development potential of less developed parts of the country. The aim of this paper is to illustrate the effect of establishment of a new dry port on regional development through increased development index. Details of regional development index calculation are presented in the paper, and an example of the calculation containing the actual data for the regions/counties of the Republic of Croatia is given. A simulation of regional development index calculation in case of establishment of a new dry port was run and presented. The simulation of development index increase as a result of dry port establishment in the town of

\section{KEY WORDS}

$\sim$ Dry port establishment,

$\sim$ Regional development

$\sim$ Increase

$\sim$ Regional development index

\author{
a. City of Zagreb, Croatia \\ e-mail: ivica.lovric@zagreb.hr \\ b. Institute of Traffic and Communications, Croatia \\ e-mail: dbartulovic@gmail.com
}

c. Croatian Academy of Sciences and Arts, Institute of Traffic and Communications, Zagreb, Croatia

e-mail: ssteiener@hazu.hr

doi: 10.7225/toms.v09.n02.012

This work is licensed under (cc) BY
Vinkovci in the Vukovar-Srijem County was conducted. Vinkovci was chosen primarily owing to its favourable geographic position in the TEN-T network connecting Croatia with various destinations through the Orient East-Med Corridor or RhineDanube Corridor, existing infrastructure that can be used for new dry port terminal, and the fact that Vukovar-Srijem is one of the most undeveloped regions (counties) in Croatia. The results have shown that the regional development index would increase in the region/ county of dry port establishment. The contribution of this research is that the paper proves the influence of dry port establishment on regional development, with emphasis on the number of newly employed persons and the effect thereof on regional development index indicators.

\section{INTRODUCTION}

Dry ports are inland freight terminals directly connected to one or more seaports where activities such as freight consolidation, custom services, logistic activities, warehousing, and other value-added services are provided. Dry ports can move goods from the road to more energy efficient and environmentally friendly modes of transportation (such as rail), reduce congestion in cities, make handling of goods in seaports more efficient and make it easier for carriers to improve logistics solutions in seaport hinterland. The goal of the Regional Development Policy of the Republic of Croatia is to contribute to the identification of priority activities that would strengthen the development potential of all Croatian regions, reduce regional disparities, strengthen and build the development potential of less developed parts of the country. In addition to many advantages brought by dry ports, this paper intends to demonstrate the effect of dry port establishment on regional development. 
The aim of this paper is to prove that dry port establishment would increase the regional development index, i.e. to illustrate the effect of dry port establishment on regional development. Details of regional development index calculation are presented in the paper, and an example of the calculation is given containing the actual data for the regions/ counties of the Republic of Croatia.

A parallel was drawn between dry port establishment and the factors influenced thereby, i.e. the defined national indicators in the Republic of Croatia used to calculate the regional development index of an individual county/ region. The emphasis is primarily on the number of newly employed persons in case of dry port establishment.

The method of calculation selected was defined by the national authorities of the Republic of Croatia, and is explained and used to simulate the actual conditions in case of dry port establishment (specifically in Vinkovci, i.e. in the Vukovar-Srijem County). This method was chosen primarily because it is the best way to simulate the actual situation in case of dry port establishment.

The results have shown that dry port establishment with emphasis on the number of newly employed persons, would increase the regional development index of the observed county/ region.

The simulation of regional development index calculation with a newly established dry port was run and presented. An increase of the development index by dry port establishment was simulated by running the scenario of dry port establishment in the Vukovar-Srijem County in the Republic of Croatia. The results of the simulation show the regional development index increased owing to dry port establishment.

\section{LITERATURE OVERVIEW: CONCEPT AND ADVANTAGES OF DRY PORT ESTABLISHMENT}

Literature overview is divided into two sections. The first section covers previous research on the concept and advantages of dry ports. The second section covers literature on the influence of dry port establishment on regional development.

\subsection{Concept and Advantages of Dry Ports: a Chronological Overview of Literature}

The most common factors influencing dry port implementation are infrastructure, land use, environment, and regulations. Hence, the same factors reduce the efficiency of freight movement on land access routes to and from seaports (Roso, 2008).

The dry port concept can help identify ways to shift freight volumes from roads to more energy efficient modes of transportation less harmful to the environment, relieve seaport cities from some congestion and facilitate improved logistics solutions for shippers in the port's hinterland (Roso et al., 2009).

For various reasons, global supply chains are getting stretched further into the hinterland from gateway seaports. This single fact enhances the importance of dry ports (Chandrakant, 2011).

According to FDT, a dry port is an intermodal terminal situated in the hinterland servicing a region connected with one or several ports by rail and/or road transport, offering specialised services between the dry port and overseas destinations. Dry port is usually container-oriented and provides all logistics facilities required by shipping and forwarding agents in a port. An important aspect worth mentioning in the context of the dry port concept are value-added services providing dry port users extra values such as saved time, convenience, reduced operational costs, etc. (FDT, 2011).

Hanaoka and Regmi pointed out that the volume of international trade and freight transport in Asia has seen fast growth in the recent decades. The resulting environmental impact of freight transport operations has become a major cause of concern. Intermodal transport recently gained prominence due to its potential to offer door-to-door service through the integration of various modes of transportation in the logistics chain, improved coordination and services, and the development of intermodal interfaces. The development of intermodal transport requires transport links, nodes, and services. The development of dry ports, an important component of intermodal transport, could play a major role in promoting intermodal transport (Hanaoka and Regmi, 2011).

The basic idea behind the dry port concept is more efficient seaport access, movement of the seaport's interface inland with the shift of flows from road to rail. The application of the concept results in the reduction of road transport to/from the seaport together with the associated broad social and environmental benefits (Black et al., 2018).

As container transport volumes continue to grow, sea flow generates almost proportionate inland flow; connections with the hinterland will become critical factors for seaport functionality. Intermodal transport with dry ports could be a potential solution for seaport terminal congestion, as well as for better seaport inland access (Roso, 2013).

Rožić and others stated that technical-technological advancements and globalization influence the development of logistics and distribution methods from the point of manufacture to the point of consumption. To make this process as successful as possible, logistics-distribution centers where goods are collected, stored, upgraded, and prepared for further distribution to customers need to be built. One of the possible functions of logistics distribution centers is their transformation to so called "inland port terminals" (dry ports) (Rožić et al., 2013). 
An increase in sea freight flows generates an almost proportionate increase in inland freight flows, and what takes place inland will influence the ability of intermodal transport systems to further accommodate the growth of international trade. This could be facilitated by dry ports developed to support both seaport operations and the overall operations of intermodal transport systems (Bask et al., 2014).

Current trends in maritime logistics often consider the presence of inland freight terminals where consolidation of goods, customs services, information processing activities, short-term storage and value-added manufacturing services for containerized goods take place before shipment to further destinations. Dry ports are defined as inland freight terminals directly connected to one or more seaports with high-capacity means of transportation, where customers can drop and pick up their standardized units as if directly at a seaport. The benefits of introduction of one or more dry ports into freight distribution was confirmed by several experiences in terms of logistics integration and port regionalization (Crainic et al., 2015; Olah et al., 2018; Bask et al., 2014; Roso et al., 2009).

With respect to the assessment of the development of dry ports in Germany and Europe, extensive data are regularly collected. The collected data give an in-depth insight into the status quo of the dry ports (national or international) studied and facilitate ranking to identify, e.g. best practices (Olah et al., 2018).

\subsection{Dry Port Impact on Regional Development: a Chronological Overview of Literature}

According to Notteboom and Rodrigue, logistics integration and network orientation in the port and maritime industry have redefined the functional role of ports in value chains and generated new patterns of freight distribution and new approaches to port hierarchy. The existing models of spatial and functional evolution of ports and port systems only partially fit into the new freight distribution paradigm. Their research aims to introduce a port regionalization stage in port and port system development (Notteboom and Rodrigue, 2005).

$\mathrm{Ng}$ and Gujar (2009) studied dry ports in India with emphasis on regional development around dry ports that could attract users. Value added services offered at dry ports can make a region more attractive to actors in its immediate vicinity, as well as attract potential new users from more remote locations $(\mathrm{Ng}$ and Gujar, 2009).

$\mathrm{Ng}$ and Tongzon stated that since a dry port acts as a seaport's inland interface, shifting port services to an inland region, it provides a stimulus for development and generates new employment. Furthermore, regional development might positively influence competitiveness by maximizing the use of existing infrastructure and generating trade volumes. They went so far as to declare that dry ports were catalysts for regional development, at least in India ( $\mathrm{Ng}$ and Tongzon, 2010).

In 2010, Rodrigue and Notteboom focused on a particular dimension of the regionalization paradigm, i.e. the evolving role of intermediate hubs. It is argued that, in addition to hinterland-based regionalization, there is also a foreland-based regionalization where intermediate hubs capture the maritime hinterland. This intensity and viability of processes of forelandbased regionalization depend on multiple geographical, technical, and market-related factors, and the paper identifies and analyses these underlying parameters (Rodrigue and Notteboom, 2010).

Contemporary economic development has underlined the importance of establishing distribution centers at appropriate locations in developing economies. In 2011, $\mathrm{Ng}$ and Cetin examined the locational characteristics of distribution centers in developing economies ( $\mathrm{Ng}$ and Cetin, 2011).

Wilmsmeier and others examined the spatial development of freight infrastructure, and developed a conceptual model that draws attention to the directional development of intermodal corridors in relation to inland terminals. They presented different approaches to the development of inland terminal facilities, elaborated government strategies and policies in terms of dry port regulation, and developed a conceptual model of directional development: inside-out and outside-in (Wilmsmeier et al., 2011).

Flämig and Hesse (2011) put an emphasis on dry ports in the context of port regionalization. Their paper specifically deals with dry ports as a challenge for planning, policy, and metropolitan governance in the vicinity of seaports. Flämig and Hesse also adopted a long-term perspective and investigated the positioning of dry ports. The authors considered the potential consequences of the development of dry ports as elements of port regionalization strategies, i.e. the changes in transportation flow management, land use, governance, and planning (Flamig and Hesse, 2011).

According to $\mathrm{Li}$ and Jiang, reaching the vast economic hinterland and suppling it with goods have become strategic problems for port operators. In addition, the establishment of a low-cost and highly efficient transportation and customs clearance route has become an inevitable requirement for the regional development of the hinterland (Li and Jiang, 2014).

Shi and $\mathrm{Li}$, studying the impact of the global supply chain and regional economic development, proposed different perspectives for analysing the development of port hinterland and applied these perspectives to Shenzhen Port in China. Due to the changing nature of a port's function, hinterland development was viewed from physical, logistics, and macroeconomic perspectives, and the influencing factors were analysed from the shippers' viewpoint in terms of three driving forces: space, value, and organization (Shi and Li, 2016). 
The recent development of dry ports in the hinterland, feeder service networks, and heavy foreign trade traffic make the ports in Bohai Bay a unique case in the analysis of inter-port connectivity and competitiveness. Using an integrated port connectivity index to define the above features, the advantages and challenges of individual ports can be assessed in a dynamic interconnected environment. The model presented by Wang and others can be used to obtain unbiased port development strategies for each port, to ensure long-term sustainability (Wang et al, 2016).

Agallos stated that ports are important gateways for domestic and global trade since approximately $80 \%$ of the world trade depends on maritime transport. In the globalized world where distances are being continually compressed, the role of ports in local communities is becoming increasingly important. However, the relationship between regional development and port activity, as indicated by various studies, is a complex issue and an important field of conflict. The aim was to develop a complex indicator assessment of port sustainability on a comparable basis (Agallos, 2016).

In the case of Iran, establishing a dry port in the province of Yazd could potentially increase freight transit in that country and foster development (Dorostkar et al., 2016).

In 2017, Dragović and others stated that the simulation modelling of shore-side and sea-side port operations constitutes a fundamental prerequisite for effective project planning in port development, as the influence of numerous often interactive parameters has to be addressed at an early stage to account for the optimum supply of port facilities and services to meet current and future demand (Dragović et al., 2017).

The application of mixed methods was proposed in dry port research to provide a multidimensional insight into seaport research issues. Jeevan and others provided guidance on the application of mixed methods in dry port research and demonstrated that mixed method research is capable of providing comprehensive results through integration of qualitative and quantitative results in a single research (Jeevan et al., 2019).

Nguyen and Notteboom defined the generic characteristics of dry ports by carrying out an analysis on a large sample of dry ports worldwide. The data collected include the terminologies used, actors driving the development, terminal throughput, total area, services provided and connection with corresponding seaports. Using statistical analysis, the paper examines how dry port parameters are influenced by different terminal set ups, like sea-driven and land-driven development, developed and developing systems, dry port functions, specifications of seaports with which the dry port is connected, i.e. seaport traffic, connectivity, utilization, etc. and the transport leg linking dry ports and seaports. The findings could be applied to the planning and development of inland nodes from the perspectives of different stakeholders (Nguyen and Notteboom, 2019).

Khaslavskaya and Roso stated that dry ports faced a variety of challenges in implementation and development stages in the form of existing social, political, environmental, and financial regulations or the lack thereof, as well as technical and technological development, land and infrastructure use, location and optimization issues, development and availability of infrastructure, stakeholder interests, investments and competitive business environment. At the same time, their research shows that dry ports could bring significant benefits to the stakeholders involved in hinterland transport operations by improving distribution systems, reducing direct and indirect logistics costs, stimulating regional development, and lowering the level of transportation emissions (Khaslavskaya and Roso, 2020).

Based on existing literature dry ports can be concluded to have a significant impact on regional development. Studying the factors influenced by dry port establishment and the method of calculation of the regional development index of a county/ region (specifically in the Republic of Croatia), a correlation was found between dry port establishment and regional development index calculation, i.e. the number of newly employed persons, as well as other relevant parameters: income per capita, budget revenues per capita, and education rate. The aim of this paper is to fill a hole in existing literature by providing an example of regional development index increase due to dry port establishment, by simulating the impact thereof using a defined mathematical method and defined parameters to calculate the regional development index in the Republic of Croatia in case of establishment of a dry port in Vinkovci, i.e. in the Vukovar-Srijem County.

\section{DEFINITION AND RELEVANCE OF THE REGIONAL DEVELOPMENT FACTOR}

The Ministry of Regional Development and EU Funds (Ministry of Regional Development and EU Funds, 2018) adopts the policy of balanced regional development aiming to further develop less developed areas of the Republic of Croatia and thus reduce regional development inequalities in the Republic of Croatia. Regional development is one of the most important guidelines of the European Union, which allocates as much as a third of its budget to the development of less developed regions in the EU, through the so-called EU cohesion policy. The policy of balanced regional development in the Republic of Croatia implies planning, implementation and coordination of regional development policy activities and the establishment of a comprehensive system of regional development programming, management, and financing. 
The enactment of the Regional Development Act followed by the adoption of the Regional Development Strategy of the Republic of Croatia laid the foundations for regional development policy management, aimed at building the overall development potential of the Republic of Croatia.

In an effort to reduce imbalances in the development of certain areas and help create the preconditions for sustainable economic and social development, programs and measures for the construction and modernization of municipal and social infrastructure based on partnership and solidarity are being implemented.

In accordance with the Regional Development Act of the Republic of Croatia and its amendment (Regional Development Act of the Republic of Croatia, 2014), the Ministry of Regional Development and EU Funds (Ministry of Regional Development and EU Funds, 2018) is conducting an assessment and development index-based classification of all units of local and regional self-government units (LRUs) in the Republic of Croatia.

Amendments to the Act that entered into force on 13 December 2017 (Amendment of Regional Development Act of the Republic of Croatia, 2017) improved the legal framework regulating the procedure of LRU assessment and classification depending on the level of development and the method of identifying less developed areas.

The new model of development index calculation is based on an expert study titled "Evaluation of the Existing and Proposal of a New Model of Index Calculation and Calculation of the New Development Index of Local and Regional Self-Government Units in the Republic of Croatia" prepared by the Centre for Local Economic Development (CLER, 2017) for the Ministry.

Following the adoption of amendments to the Act and the development of a new model of development index calculation, a new Regulation on the Development Index was adopted (Regulation on the Development Index, 2017). The Regulation identifies the basic indicators for development index calculation, their calculation and data sources, and the method of development index calculation.

The development index facilitates the measurement of the level of development of LRUs in the Republic of Croatia. The classification or categorization of all territorial units according to development is based on the modern understanding of regional policy which, although focused on the least developed areas, encourages the development of entire territory of a country. The categorization of all territorial units facilitates better regulation of the key issue of the amount of regional development incentives. The establishment of a direct correlation between the amount of regional development incentives and the level of development allowed the creation of a quality framework encouraging the development of all local and county units depending on their individual level of development. Likewise, this approach allows the inclusion and exclusion of individual units from the system of assisted areas (less developed areas) depending on changes in their development level.

Regional self-government units are classified into four groups (Regulation on the Development Index, 2017):

I. group are regional self-government units which, according to the value of the index, are in the second half of the belowaverage ranked regional self-government units;

II. group are regional self-government units which, according to the value of the index, are in the first half of the below-average ranked regional self-government units;

III. group are regional self-government units which, according to the value of the index, are in the second half of the aboveaverage ranked regional self-government units;

IV. group are regional self-government units which, according to the value of the index, are in the first half of the above-average ranked regional self-government units.

Local self-government units are divided into eight groups (Regulation on the Development Index, 2017):

I. group are local self-government units which, according to the value of the index, are in the last quarter of below-average ranked local self-government units;

II. group are local self-government units which, according to the value of the index, are in the third quarter of below-average ranked local self-government units;

III. group are local self-government units which, according to the value of the index, are in the second quarter of belowaverage ranked local self-government units;

IV. group are local self-government units which, according to the value of the index, are in the first quarter of below-average ranked local self-government units;

V. group are local self-government units which, according to the value of the index, are in the last quarter of above-average ranked local self-government units;

VI. group are local self-government units which, according to the value of the index, are in the third quarter of above-average ranked local self-government units;

VII. group are local self-government units which, according to the value of the index, are in the second quarter of aboveaverage ranked local self-government units;

VIII. group are local self-government units which, according to the value of the index, are in the first quarter of above-average ranked local self-government units.

\section{REGIONAL DEVELOPMENT INDEX}

According to the Regulation on the Development Index (Regulation on the Development Index, 2017), the development index of a regional or local self-government unit in the Republic of Croatia is calculated on the basis of the following basic indicators:

5. unemployment rate,

6. income per capita, 
7. budget revenues per capita,

8. general population movement,

9. education rate,

10. ageing index.

\subsection{Unemployment Rate}

Unemployment rate is calculated as the ratio of the number of unemployed and the sum of all employed and unemployed persons on the territory of a local or regional self-government unit. Unemployment rate is calculated using the following equation (Regulation on the Development Index, 2017):

$$
x_{1}=\frac{N_{(0)}}{R S_{(0)}}
$$

where variables are:

$N_{(0)}$ - the number of the unemployed on the territory of a particular local or regional self-government unit,

$R S_{(0)}$ - the sum of all employed and unemployed persons on the territory of a particular local or regional self-government unit.

This indicator was calculated using the data of the Croatian Employment Service on the number of registered unemployed persons and the data of the Croatian Tax Administration on the number of employed persons at the level of local or regional selfgovernment units over a one-year period.

\subsection{Income Per Capita}

Income per capita is determined in keeping with the act governing income tax, and includes income earned from nonself-employment and income earned from self-employment. The total amount of income also includes profit from independent activity realized in a given tax period (calendar year) on the territory of a local or regional self-government unit for which the calculation is made. Income Tax Act defines income from selfemployment as income less deductions and retained loss. Profit is defined as profit after prescribed reductions and increases in profit, in accordance with the Income Tax Act.

Income per capita is calculated as the ratio of the total amount of income earned in a given tax period (calendar year) by taxpayers with permanent residence on the territory of a local or regional self-government unit for which the calculation is made, and the number of residents living on the territory of that unit. Income per capita is calculated using the following equation (Regulation on the Development Index, 2017):
$x_{2}=\frac{D_{i}}{P_{i}}$

where variables are:

$D_{i}$ - the sum of incomes earned by residents in the i-th local or regional self-government unit during one calendar year,

$P_{i}$ - estimated number of residents in the i-th local or regional self-government unit at the end of the year.

This indicator was calculated using the data of the Croatian Tax Administration on paid incomes and the data of the Croatian Bureau of Statistics on the number of residents of local or regional self-government units.

\subsection{Budget Revenues Per Capita}

Budget revenues of local or regional self-government units per capita are calculated as the ratio of realized revenues of local or regional self-government unit less income:

- from domestic and foreign aids and donations or means of fiscal equalization,

- from special contracts: co-financing of local selfgovernment by citizens,

- realized based on additional shares in income tax and equalization aid for financing decentralized functions,

- from the sale of non-financial assets,

- from surtax on income tax, and

- the number of residents on the territory of a local or regional self-government unit.

Budget revenue per capita is calculated using the following equation (Regulation on the Development Index, 2017):

$x_{3}=\frac{I P P_{i}}{P_{i}}$

where variables are:

$I P P_{i}$ - the amount of budget revenues generated in the area of the i-th local or regional self-government unit during one calendar year, i.e. the amount of budget revenues generated on the territory of the i-th regional self-government unit and all of its local self-government units,

$P_{i}$ - the estimate of the number of residents in the i-th local or regional self-government unit at the end of the year.

This indicator was calculated using the data of the Ministry of Finance on budget revenues of local or regional selfgovernment units and the Croatian Bureau of Statistics on the number of residents of local or regional self-government units. 


\subsection{General Population Movement}

The general movement of the population is calculated as the ratio of a comparable number of residents of a local or regional self-government unit in the last available ten-year period. The general movement of the population is calculated using the following equation (Regulation on the Development Index, 2017):

$x_{4}=\frac{P_{n}}{P_{n-10}}$

where variables are:

$P_{n}$ - the estimated number of residents in the i-th local or regional self-government unit in the observed year,

$P_{n-10}$ - the estimated number of residents of the i-th local or regional self-government unit in the last available ten-year period.

This indicator was calculated using the data of the Croatian Bureau of Statistics on the number of residents of local and regional self-government units.

\subsection{Education Rate}

Education rate is the share of population with completed higher education in the total population aged 20-65 in the area of a local or regional self-government unit. The education rate is calculated using the following equation (Regulation on the Development Index, 2017):

$x_{5}=\frac{P_{(h e+)}}{P_{(20+)}}$

where variables are:

$P_{(h e+)}$ - the number of residents in the i-th local or regional self-government unit with completed higher education,

$P_{(20+)}$ - the number of residents in the i-th local or regional self-government unit aged 20-65.

This indicator was calculated using the data of the Croatian Bureau of Statistics on the educational structure of the population of the Republic of Croatia and the number of population aged 20-65 at the level of local or regional self-government units.

\subsection{Ageing Index}

The ageing index is calculated as the percentage of the population aged 60 and above in relation to the population aged $0-19$. The ageing index is calculated using the following equation (Regulation on the Development Index, 2017):

$$
x_{6}=\frac{P_{(60+)}}{P_{(0-19)}}
$$

where variables are:

$P_{(60+)}$ - the number of residents in the i-th local or regional self-government unit aged 60 and above,

$P_{(0-19)}$ - the number of residents in the i-th local or regional self-government unit aged 0-19.

This indicator was calculated using the data of the Croatian Bureau of Statistics on age contingents of the population at the level of local or regional self-government units.

\section{REGIONAL DEVELOPMENT INDEX CALCULATION METHODOLOGY}

The value of the development index is calculated as an adjusted average of the standardized values of the six previously mentioned basic indicators over a given period of time. The value of the development index is calculated to three decimal places.

Calculation is based on the so-called z-score methodology (CLER, 2017; Bogdan et al., 2019). The z-score method is a nonlinear method for creating composite indices that transforms the values of individual indicators into standardized values and summarizes them into a composite index using the arithmetic mean and a penalty coefficient. This method was developed by the authors Mazziotta and Pareto, and is known in the scientific and professional literature as the Mazziotta-Pareto index (De Muro et al., 2011; Mazziotta and Pareto, 2016). The MazziottaPareto index is designed to solve the problem of objective measurement, evaluation, comparison and ranking of units at higher or lower territorial-administrative levels depending on their development in a given period of time when individual unit(s) have uncoordinated sets of indicators, i.e. when according to some indicators they achieve above-average results, and according to others below-average results.

The development index is interpreted so that local or regional self-government units with an index value greater than 100 are classified as units with above-average development level, while local or regional self-government units with an index value under 100 are classified as units with below-average development level. 
The process of indicator standardization for the income per capita, budget revenues per capita, general population movements and education rate indicators, whose high values are positive in the context of development, is carried out using the following equation (Regulation on the Development Index, 2017):

$Z_{i j}=100+\frac{x_{i j}-M_{x j}}{S_{x j}} * 10$

while the process of indicator standardization for the unemployment rate and ageing index indicators, whose high values are negative in the context of development, is carried out using the following equation (Regulation on the Development Index, 2017):

$$
Z_{i j}=100-\frac{x_{i j}-M_{x j}}{S_{x j}} * 10
$$

where variables are:

$Z_{i j}$ - standardized value ( $z$-score) of basic indicator $x$ for an observed local or regional self-government unit,

$x_{i j}$ - the value of the basic indicator $x$ for an observed local or regional self-government unit,

$M_{x j}$ - the arithmetic mean of the basic indicator $x$ for all units of local or regional self-government,

$S_{x j}$ - standard deviation of the set of values of the basic indicator $x$ for all units of local or regional self-government.

The steps of aggregating the standardized values of the basic indicators obtained by the previous equations into the development index are carried out using the arithmetic mean method and the penalty coefficient as shown in the following equation (Regulation on the Development Index, 2017):

$I_{i}=M_{z i}-\left(S_{z i}^{*} C v_{i}\right)$

where variables are: unit,

$I_{i}$-development index of a local or regional self-government

$M_{z i}$-arithmetic mean of standardized values of all indicators for an observed unit of local or regional self-government,
$\left(S_{z i}{ }^{*} C V_{i}\right)$ - penalty coefficient for an observed unit of local or regional self-government,

$S_{z i}$ - standard deviation of the set of standardized values of all indicators for an observed unit of local or regional selfgovernment,

$C v_{i}$ - coefficient of variation of a set of standardized values of all indicators for an observed unit of local or regional selfgovernment.

\section{EXAMPLE OF REGIONAL DEVELOPMENT INDEX CALCULATION}

The calculation of the basic development index indicators requires the data requisite to calculate each basic indicator. All variables are data taken from statistical reports of the Croatian Employment Service, the Croatian Tax Administration, the Ministry of Finance and the Croatian Bureau of Statistics (Regulation on the Development Index, 2017), i.e. they represent constants in the mathematical sense.

If development index calculation indicators are defined as follows:

$x_{1}$ - unemployment rate

$x_{1}=\frac{N_{(0)}}{R S_{(0)}}$

$x_{2}$ - income per capita

$x_{2}=\frac{D_{i}}{P_{i}}$

$x_{3}$ - budget revenues per capita

$x_{3}=\frac{I P P_{i}}{P_{i}}$

$x_{4}$-general population movement

$x_{4}=\frac{P_{n}}{P_{n-10}}$ 
$x_{5}$ - education rate

$x_{5}=\frac{P_{(\text {he+ })}}{P_{(20+)}}$

$x_{6}$ - ageing index

$x_{6}=\frac{P_{(60+)}}{P_{(0-19)}}$

the standardized values of the indicators are as follows: $Z_{x 1 j}$ - standardized value of the unemployment rate indicator

$Z_{x 1 j}=100-\frac{x_{1 j}-M_{x 1 j}}{S_{x 1 j}} * 10$

$Z_{x 2 j}$-standardized value of the income per capita indicator

$Z_{x 2 j}=100+\frac{x_{2 j}-M_{x 2 j}}{S_{x 2 j}} * 10$

$Z_{x 3 j}$ - standardized value of the budget revenues per capita indicator

$Z_{x 3 j}=100+\frac{x_{3 j}-M_{x 3 j}}{S_{x 3 j}} * 10$

$Z_{x 4 j}$ - standardized value of general population movement indicator

$Z_{x 4 j}=100+\frac{x_{4 j}-M_{x 4 j}}{S_{x 4 j}} * 10$
$Z_{x 5 j}$ - standardized value of the education rate indicator

$Z_{x 5 j}=100+\frac{x_{5 j}-M_{x 5 j}}{S_{x 5 j}} * 10$

$Z_{x 6 j}$-standardized value of the ageing index indicator

$Z_{x 6 j}=100-{\frac{x_{6 j}-M_{x 6 j}}{S_{x 6 j}}}^{*} 10$

where the arithmetic mean and standard deviation are expressed with equations:

$M_{x j}=\frac{\sum_{j=1}^{m} x_{j}}{m}, m=1 \ldots 3$

$S_{x j}=\sqrt{\frac{1}{m} \sum_{j=1}^{m}\left(x_{j}-M_{x j}\right)^{2}}, m=1 \ldots 3$

and the development index is calculated as follows:

$I_{i}=M_{z i}-\left(S_{z i}^{*} C v_{i}\right)$

that is, using the following steps:

1) Arithmetic mean of standardized values of all indicators for a single local or regional self-government unit:

$M_{Z i}=\frac{\sum_{i=1}^{n} Z_{i}}{n}, n=1 \ldots 6$

or:

$M_{Z i}=\frac{Z_{x 1 j}+Z_{x 2 j}+Z_{x 3 j}+Z_{x 4 j}+Z_{x 5 j}+Z_{x 6 j}}{6}$ 
2) Standard deviation of standardized values of all indicators for a single local or regional self-government unit:
3) Coefficient of variation of the set of standardized values of all indicators for a single local or regional self-government unit:

$$
S_{Z i}=\sqrt{\frac{1}{n} \sum_{i=1}^{n}\left(Z_{i}-M_{Z i}\right)^{2}}, n=1 \ldots 6 \quad \text { (27) } \quad c v_{i}=\frac{S_{Z i}}{M_{Z i}}
$$

Table 1.

Example of the values of basic indicators required for regional development index calculation.

Source: Authors according to (Ministry of Regional Development and EU Funds, 2018)

\begin{tabular}{|c|c|c|c|c|c|c|}
\hline \multirow[t]{3}{*}{ County } & \multicolumn{6}{|c|}{ Values of basic indicators for the county (regional unit) } \\
\hline & $\mathbf{x} 1$ & $\mathbf{x 2}$ & x3 & $\mathbf{x 4}$ & $\mathbf{x 5}$ & $x 6$ \\
\hline & $\begin{array}{l}\text { Unemployment } \\
\text { rate }\end{array}$ & $\begin{array}{l}\text { Income per } \\
\text { capita }\end{array}$ & $\begin{array}{l}\text { Budget } \\
\text { revenues per } \\
\text { capita }\end{array}$ & $\begin{array}{l}\text { General } \\
\text { population } \\
\text { movement }\end{array}$ & Education rate & Ageing index \\
\hline City of Zagreb & 0.1007 & $44,733.21$ & $6,232.49$ & 103.10 & 0.3935 & 118.9 \\
\hline Istria & 0.0654 & $35,191.17$ & $5,535.63$ & 101.17 & 0.2250 & 136.8 \\
\hline Dubrovnik-Neretva & 0.1323 & $30,904.76$ & $4,848.62$ & 101.07 & 0.2618 & 109.4 \\
\hline Zagreb & 0.1079 & $32,579.23$ & $3,222.84$ & 100.54 & 0.1678 & 100.1 \\
\hline Primorje-Gorski Kotar & 0.1141 & $35,367.41$ & $5,229.00$ & 96.91 & 0.2747 & 155.3 \\
\hline Zadar & 0.1200 & $26,630.15$ & $3,908.88$ & 102.30 & 0.2085 & 117.4 \\
\hline Split-Dalmatia & 0.1923 & $28,190.12$ & $3,476.57$ & 99.75 & 0.2472 & 102.3 \\
\hline Varaždin & 0.0974 & $28,714.71$ & $2,387.25$ & 95.45 & 0.1628 & 107.3 \\
\hline Međimurje & 0.1164 & $24,835.25$ & $2,077.08$ & 97.99 & 0.1367 & 91.8 \\
\hline Krapina-Zagorje & 0.1135 & $28,783.48$ & $2,092.17$ & 93.73 & 0.1266 & 112.6 \\
\hline Koprivnica-Križevci & 0.1370 & $24,587.95$ & $2,703.28$ & 93.24 & 0.1483 & 110.5 \\
\hline Šibenik-Knin & 0.1622 & $27,315.29$ & $3,283.90$ & 91.58 & 0.1944 & 146.1 \\
\hline Osijek-Baranja & 0.2369 & $26,216.25$ & $2,271.75$ & 91.90 & 0.1749 & 106.3 \\
\hline Karlovac & 0.1728 & $29,715.33$ & $2,547.26$ & 88.93 & 0.1836 & 149.0 \\
\hline Požega-Slavonia & 0.1814 & $22,925.23$ & $1,550.25$ & 87.42 & 0.1429 & 99.2 \\
\hline Brod-Posavina & 0.2143 & $22,105.97$ & $1,550.91$ & 90.09 & 0.1342 & 96.5 \\
\hline Bjelovar-Bilogora & 0.2246 & $23,529.44$ & $1,912.61$ & 89.02 & 0.1310 & 114.9 \\
\hline Lika-Senj & 0.1696 & $27,401.26$ & $3,392.29$ & 86.29 & 0.1596 & 166.0 \\
\hline Vukovar-Srijem & 0.2431 & $22,256.51$ & $1,627.30$ & 88.41 & 0.1320 & 98.3 \\
\hline Sisak-Moslavina & 0.2461 & $27,197.16$ & $2,502.17$ & 85.20 & 0.1481 & 131.1 \\
\hline Virovitica-Podravina & 0.2613 & $21,297.29$ & $1,872.32$ & 88.54 & 0.1145 & 103.3 \\
\hline
\end{tabular}


Table 1 gives an example of the values (data) of basic indicators for development index calculation. The values of variables required for the calculation of basic indicators were taken from Croatian Employment Service, the Croatian Tax Administration, the Ministry of Finance and the Croatian Bureau of Statistics official data for year 2016 (Croatian Employment Service, 2016; Croatian Bureau of Statistics, 2016; Croatian Bureau of Statistics, 2011; Ministry of Regional Development and EU Funds, 2018) for 21 regional self-government units i.e. counties of the Republic of Croatia.

In the next step, the arithmetic mean and standard deviation of all values of one basic indicator for all regional units (counties) are calculated:

$M_{x j}=\frac{\sum_{j=1}^{m} x_{j}}{m}, m=1 \ldots 21$

$S_{x j}=\sqrt{\frac{1}{m} \sum_{j=1}^{m}\left(x_{j}-M_{x j}\right)^{2}}, m=1 \ldots 21$

that is, the arithmetic mean and standard deviation of all values of each indicator in all regional governments are as follows:

$M_{x 1 j}=\frac{\sum_{j=1}^{m} x_{1 j}}{21}=0.16$

$S_{x 1 j}=\sqrt{\frac{1}{21} \sum_{j=1}^{m}\left(x_{1 j}-M_{x 1 j}\right)^{2}}=0.06$

$M_{x 2 j}=\frac{\sum_{j=1}^{m} x_{2 j}}{21}=28.117 .96$

$S_{x 2 j}=\sqrt{\frac{1}{21} \sum_{j=1}^{m}\left(x_{2 j}-M_{x 2 j}\right)^{2}}=5,370.96$

$M_{x 3 j}=\frac{\sum_{j=1}^{m} x_{3 j}}{21}=3,058.31$
$S_{x 3 j}=\sqrt{\frac{1}{21} \sum_{j=1}^{m}\left(x_{3 j}-M_{x 3 j}\right)^{2}}=1,348.59$

$M_{x 4 j}=\frac{\sum_{j=1}^{m} x_{4 j}}{21}=93.93$

$S_{x 4 j}=\sqrt{\frac{1}{21} \sum_{j=1}^{m}\left(x_{4 j}-M_{x 4 j}\right)^{2}}=5.66$

$M_{x 5 j}=\frac{\sum_{j=1}^{m} x_{5 j}}{21}=0.18$

$S_{x 5 j}=\sqrt{\frac{1}{21} \sum_{j=1}^{m}\left(x_{5 j}-M_{x 5 j}\right)^{2}}=0.06$

$M_{x 6 j}=\frac{\sum_{j=1}^{m} x_{6 j}}{21}=117.77$

$S_{x 6 j}=\sqrt{\frac{1}{21} \sum_{j=1}^{m}\left(x_{6 j}-M_{x 6 j}\right)^{2}}=20.78$

The next step is to calculate the standardized values of the indicators, i.e.:

$Z_{x 1 j}$ - standardized value of the unemployment rate indicator

$Z_{x 1 j}=100-\frac{x_{1 j}-M_{x 1 j}}{S_{x 1 j}} * 10$

$Z_{x 11}=100-\frac{x_{11}-M_{x 1 j}}{S_{x 1 j}} * 10=100-\frac{0,1007-0,16}{0,06} * 10=110.88$ 
All remaining 20 values are calculated in the same way: $Z_{x 12^{\prime}}$ $Z_{x 13^{\prime}} Z_{x 14^{\prime}} Z_{x 15^{\prime}} Z_{x 16^{\prime}} Z_{x 17^{\prime}} Z_{x 18^{\prime}} Z_{x 19^{\prime}} Z_{x 110^{\prime}} Z_{x 111^{\prime}} Z_{x 112^{\prime}} Z_{x 113^{\prime}} Z_{x 114^{\prime}} Z_{x 115^{\prime}}$ $Z_{x 116}, Z_{x 117}, Z_{x 118^{\prime}} Z_{x 119^{\prime}}, Z_{x 120}, Z_{x 121}$.

$Z_{x 2 j}$ is standardized value of the income per capita indicator:

$Z_{x 2 j}=100+\frac{x_{2 j}-M_{x 2 j}}{S_{x 2 j}} * 10$

$Z_{x 21}=100-\frac{x_{21}-M_{x 2 j}}{S_{x 2 j}} * 10=100-\frac{44.733,21-28.117,96}{5.370,96} * 10=130.94$

All remaining 20 values are calculated in the same way.

$Z_{x 3 j}$-standardized value of the budget revenues per capita indicator

$Z_{x 3 j}=100+\frac{x_{3 j}-M_{x 3 j}}{S_{x 3 j}} * 10$

$Z_{x 31}=100-\frac{x_{31}-M_{x 3 j}}{S_{x 3 j}} * 10=100-\frac{6.232,49-3.058,31}{1.348,59} * 10=123.54$

All remaining 20 values are calculated in the same way.

$Z_{x 4 j}$ - standardized value of general population movement indicator

$Z_{x 4 j}=100+\frac{x_{4 j}-M_{x 4 j}}{S_{x 4 j}} * 10$

$Z_{x 41}=100-\frac{x_{41}-M_{x 4 j}}{S_{x 4 j}} * 10=100-\frac{103,10-93,93}{5,66} * 10=116.19$

All remaining 20 values are calculated in the same way. $Z_{x 5 j}$-standardized value of the education rate indicator
$Z_{x 5 j}=100+\frac{x_{5 j}-M_{x 5 j}}{S_{x 5 j}} * 10$

$Z_{x 51}=100-\frac{x_{51}-M_{x 5 j}}{S_{x 5 j}} * 10=100-\frac{0,3935-0,18}{0,06} * 10=132.24$

All remaining 20 values are calculated in the same way. $Z_{x 6 j}$ - standardized value of the ageing index indicator

$$
Z_{x 6 j}=100-\frac{x_{6 j}-M_{x 6 j}}{S_{x 6 j}} * 10
$$

$$
Z_{x 61}=100-\frac{x_{61}-M_{x 6 j}}{S_{x 6 j}} * 10=100-\frac{118,9-117,77}{20,78} * 10=99.46
$$

All remaining 20 values are calculated in the same way.

In the next step, the arithmetic mean of the standardized values of all indicators for one unit of local or regional selfgovernment is calculated:

$M_{Z i}=\frac{\sum_{i=1}^{n} Z_{j}}{n}$

$M_{Z i}=\frac{Z_{x 1 j}+Z_{x 2 j}+Z_{x 3 j}+Z_{x 4 j}+Z_{x 5 j}+Z_{x 6 j}}{6}$

$M_{Z i}=\frac{Z_{x 11}+Z_{x 21}+Z_{x 31}+Z_{x 41}+Z_{x 51}+Z_{x 61}}{6}$

$110,88+130,94+123,54+116,19+132,24+99,46$

$M_{Z i}=\frac{}{6}=118.875$ 
All remaining 20 values are calculated in the same way: $M_{z 2}$, $M_{z 3^{\prime}}, M_{z 4^{\prime}} M_{z 5^{\prime}}, M_{z 6^{\prime}} M_{z 7^{\prime}}, M_{z 8^{\prime}} M_{z 9^{\prime}}, M_{z 10^{\prime}} M_{z 11^{\prime}}, M_{z 12^{\prime}} M_{z 13^{\prime}} M_{z 14^{\prime}} M_{z 15^{\prime}}$ $M_{z 16^{\prime}}, M_{z 17^{\prime}}, M_{z 18^{\prime}}, M_{z 19^{\prime}}, M_{z 20^{\prime}}, M_{z 21}$.

The standard deviation of the standardized values of all indicators for a single local or regional self-government unit is calculated by the following equation:

$S_{Z i}=\sqrt{\frac{1}{n} \sum_{i=1}^{n}\left(Z_{i}-M_{Z i}\right)^{2}}$

$S_{Z i}=\sqrt{\frac{1}{6} \sum_{i=1}^{n}\left(Z_{i}-M_{Z i}\right)^{2}}=11.504$

All remaining 20 values are calculated in the same way: $S_{z 2^{\prime}}$

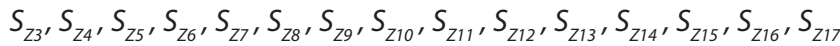
$, S_{z 18}, S_{z 19}, S_{z 20^{\prime}} S_{z 21}$.

The coefficient of variation of the set of standardized values of all indicators for a single local or regional self-government unit is calculated by the following equation:

$c v_{i}=\frac{S_{Z i}}{M_{Z i}}$

$c v_{i}=\frac{S_{Z i}}{M_{Z i}}=\frac{11,504}{118,875}=0.097$

In the last step, the development index is calculated using the equation:

$I_{i}=M_{z i}-\left(S_{z i}^{*} C v_{i}\right)$

$I_{1}=M_{z 1}-\left(S_{z 1}{ }^{*} C v_{1}\right)=118,875-(11,504 * 0,097)=117.762$
Thus, according to the example of development index calculation by counties (Table 2), I1 represents the development index of the City of Zagreb.

$$
\mathrm{I}_{1}=\mathrm{I}_{\text {CITY OF ZAGREB }}=117.762 \text {. }
$$

The development index of all remaining 20 counties is calculated in the same way:

$$
\begin{aligned}
& I_{2}=I_{\text {ISTRIA }}=108.972 \\
& I_{3}=I_{\text {DUBROVAČKO-NERETVANSKA }}=108.588 \\
& I_{4}=I_{\text {ZAGREB }}=105.894 \\
& I_{5}=I_{\text {PRIMORJE-GORASKI KOTAR }}=105.284 \\
& I_{6}=I_{\text {ZADAR }}=104.655 \\
& I_{7}=I_{\text {SPLIT-DALMATIA }}=103.939 \\
& I_{8}=I_{\text {VARAŻDIN }}=101.720 \\
& I_{9}=I_{\text {MEEIMURJE }}=100.508 \\
& I_{10}=I_{\text {KRAPINA-ZAGORJE }}=98.979 \\
& I_{11}=I_{\text {KOPRIVNICA-KRIŻEVCI }}=98.498 \\
& I_{12}=I_{\text {ŠIBENII-KNIN }}=97.049 \\
& I_{13}=I_{\text {OSIJEK-BARANJA }}=96.012 \\
& I_{14}=I_{\text {KARLOVAC }}=95.198 \\
& I_{15}=I_{\text {POŻEGA-SLAVONIA }}=93.954 \\
& I_{16}=I_{\text {BROD-POSAVINA }}=93.454 \\
& I_{17}=I_{\text {BJELOVAR-BILOGORA }}=92.582 \\
& I_{18}=I_{\text {LIKA-SENJ }}=92.392 \\
& I_{19}=I_{\text {VUKOVAR-SRIJEM }}=91.995 \\
& I_{20}=I_{\text {SISAK-MOSLAVINA }}=91.704 \\
& I_{21}=I_{\text {VIROVITICA-PODRAVINA }}=90.670
\end{aligned}
$$

The example of development index calculation by counties (regional self-government units) in the Republic of Croatia (Table 2) shows the calculation of the development index for each county of the Republic of Croatia based on current data and in the current scenario without established dry port.

All counties and their development indexes are presented in Figure 1, in keeping with the development index results by counties of the Republic of Croatia (Table 2). The threshold is 100, and counties below 100 are counties with below-average development level (undeveloped) or assisted counties. 
Table 2.

Calculation of development index by counties in the Republic of Croatia.

\begin{tabular}{|c|c|c|c|c|c|c|c|c|c|c|c|c|}
\hline \multirow[t]{3}{*}{ County } & \multicolumn{8}{|c|}{ Values of basic indicators for the region/ county } & \multicolumn{4}{|c|}{ Values of standardized indicators for } \\
\hline & x1 & $\mathbf{x} 2$ & x3 & $\mathrm{x} 4$ & x5 & $x 6$ & $\mathbf{x} 1$ & & & & & $\mathbf{x} 2$ \\
\hline & $\begin{array}{l}\text { Unemployment } \\
\text { Rate }\end{array}$ & $\begin{array}{l}\text { Income Per } \\
\text { Capita }\end{array}$ & $\begin{array}{l}\text { Budget } \\
\text { Revenues } \\
\text { per Capita }\end{array}$ & $\begin{array}{l}\text { General } \\
\text { Population } \\
\text { Movement }\end{array}$ & $\begin{array}{l}\text { Education } \\
\text { Rate }\end{array}$ & $\begin{array}{l}\text { Ageing } \\
\text { Index }\end{array}$ & $\mathrm{Mxj}$ & Sxj & $\begin{array}{l}\text { Unemployment } \\
\text { Rate (-) }\end{array}$ & $M \times j$ & Sxj & $\begin{array}{l}\text { Income } \\
\text { Per } \\
\text { Capita }\end{array}$ \\
\hline City of Zagreb & 0.1007 & $44,733.21$ & $6,232.49$ & 103.1 & 0.3935 & 118.9 & 0.16 & 0.06 & 110.88 & $28,117.96$ & $5,370.96$ & 130.94 \\
\hline Bjelovar-Bilogora & 0.2246 & $23,529.44$ & $1,912.61$ & 89.02 & 0.131 & 114.9 & 0.16 & 0.06 & 89.02 & $28,117.96$ & $5,370.96$ & 91.46 \\
\hline Brod-Posavina & 0.2143 & $22,105.97$ & $1,550.91$ & 90.09 & 0.1342 & 96.5 & 0.16 & 0.06 & 90.84 & $28,117.96$ & $5,370.96$ & 88.81 \\
\hline Dubrovnik-Neretva & 0.1323 & $30,904.76$ & $4,848.62$ & 101.07 & 0.2618 & 109.4 & 0.16 & 0.06 & 105.31 & $28,117.96$ & $5,370.96$ & 105.19 \\
\hline Istria & 0.0654 & $35,191.17$ & $5,535.63$ & 101.17 & 0.225 & 136.8 & 0.16 & 0.06 & 117.11 & $28,117.96$ & $5,370.96$ & 113.17 \\
\hline Karlovac & 0.1728 & $29,715.33$ & $2,547.26$ & 88.93 & 0.1836 & 149 & 0.16 & 0.06 & 98.16 & $28,117.96$ & $5,370.96$ & 102.98 \\
\hline Koprivnica-Križevci & 0.137 & $24,587.95$ & $2,703.28$ & 93.24 & 0.1483 & 110.5 & 0.16 & 0.06 & 104.48 & $28,117.96$ & $5,370.96$ & 93.43 \\
\hline Krapina-Zagorje & 0.1135 & $28,783.48$ & $2,092.17$ & 93.73 & 0.1266 & 112.6 & 0.16 & 0.06 & 108.63 & $28,117.96$ & $5,370.96$ & 101.24 \\
\hline Lika-Senj & 0.1696 & $27,401.26$ & $3,392.29$ & 86.29 & 0.1596 & 166 & 0.16 & 0.06 & 98.73 & $28,117.96$ & $5,370.96$ & 98.67 \\
\hline Međimurje & 0.1164 & $24,835.25$ & $2,077.08$ & 97.99 & 0.1367 & 91.8 & 0.16 & 0.06 & 108.11 & $28,117.96$ & $5,370.96$ & 93.89 \\
\hline Osijek-Baranja & 0.2369 & $26,216.25$ & $2,271.75$ & 91.9 & 0.1749 & 106.3 & 0.16 & 0.06 & 86.85 & $28,117.96$ & $5,370.96$ & 96.46 \\
\hline Požega-Slavonia & 0.1814 & $22,925.23$ & $1,550.25$ & 87.42 & 0.1429 & 99.2 & 0.16 & 0.06 & 96.64 & $28,117.96$ & $5,370.96$ & 90.34 \\
\hline Primorje-Gorski Kotar & 0.1141 & $35,367.41$ & $5,229.00$ & 96.91 & 0.2747 & 155.3 & 0.16 & 0.06 & 108.52 & $28,117.96$ & $5,370.96$ & 113.5 \\
\hline Sisak-Moslavina & 0.2461 & $27,197.16$ & $2,502.17$ & 85.2 & 0.1481 & 131.1 & 0.16 & 0.06 & 85.22 & $28,117.96$ & $5,370.96$ & 98.29 \\
\hline Split-Dalmatia & 0.1923 & $28,190.12$ & $3,476.57$ & 99.75 & 0.2472 & 102.3 & 0.16 & 0.06 & 94.72 & $28,117.96$ & $5,370.96$ & 100.14 \\
\hline Šibenik-Knin & 0.1622 & $27,315.29$ & $3,283.90$ & 91.58 & 0.1944 & 146.1 & 0.16 & 0.06 & 100.03 & $28,117.96$ & $5,370.96$ & 98.51 \\
\hline Varaždin & 0.0974 & $28,714.71$ & $2,387.25$ & 95.45 & 0.1628 & 107.3 & 0.16 & 0.06 & 111.47 & $28,117.96$ & $5,370.96$ & 101.12 \\
\hline Virovitica-Podravina & 0.2613 & $21,297.29$ & $1,872.32$ & 88.54 & 0.1145 & 103.3 & 0.16 & 0.06 & 82.54 & $28,117.96$ & $5,370.96$ & 87.31 \\
\hline Vukovar-Srijem & 0.2431 & $22,256.51$ & $1,627.30$ & 88.41 & 0.132 & 98.3 & 0.16 & 0.06 & 85.75 & $28,117.96$ & $5,370.96$ & 89.09 \\
\hline Zadar & 0.12 & $26,630.15$ & $3,908.88$ & 102.3 & 0.2085 & 117.4 & 0.16 & 0.06 & 107.48 & $28,117.96$ & $5,370.96$ & 97.23 \\
\hline Zagreb & 0.1079 & $32,579.23$ & $3,222.84$ & 100.54 & 0.1678 & 100.1 & 0.16 & 0.06 & 109.61 & $28,117.96$ & $5,370.96$ & 108.31 \\
\hline
\end{tabular}




\begin{tabular}{|c|c|c|c|c|c|c|c|c|c|c|c|c|c|c|c|}
\hline \multicolumn{12}{|c|}{ the regional unit/ county } & \multicolumn{4}{|c|}{ Regional (County) Development Index } \\
\hline & & x3 & & & $x 4$ & & & x5 & & & $x 6$ & & & & \\
\hline Mxj & Sxj & $\begin{array}{l}\text { Budget } \\
\text { Revenues } \\
\text { per Capita }\end{array}$ & Mxj & Sxj & $\begin{array}{l}\text { General } \\
\text { Population } \\
\text { Movement }\end{array}$ & Mxj & Sxj & $\begin{array}{l}\text { Education } \\
\text { Rate }\end{array}$ & Mxj & Sxj & $\begin{array}{l}\text { Ageing } \\
\text { Index } \\
(-)\end{array}$ & Mzi & Szi & cvi & li \\
\hline $3,058.31$ & $1,348.59$ & 123.54 & 93.93 & 5.66 & 116.19 & 0.18 & 0.06 & 132.24 & 117.77 & 20.78 & 99.46 & 118.875 & 11.504 & 0.097 & 117.762 \\
\hline $3,058.31$ & $1,348.59$ & 91.51 & 93.93 & 5.66 & 91.33 & 0.18 & 0.06 & 91.81 & 117.77 & 20.78 & 101.38 & 92.752 & 3.968 & 0.043 & 92.582 \\
\hline $3,058.31$ & $1,348.59$ & 88.83 & 93.93 & 5.66 & 93.21 & 0.18 & 0.06 & 92.31 & 117.77 & 20.78 & 110.24 & 94.04 & 7.426 & 0.079 & 93.454 \\
\hline $3,058.31$ & $1,348.59$ & 113.28 & 93.93 & 5.66 & 112.61 & 0.18 & 0.06 & 111.96 & 117.77 & 20.78 & 104.03 & 108.73 & 3.927 & 0.036 & 108.588 \\
\hline $3,058.31$ & $1,348.59$ & 118.37 & 93.93 & 5.66 & 112.78 & 0.18 & 0.06 & 106.29 & 117.77 & 20.78 & 90.84 & 109.76 & 9.3 & 0.085 & 108.972 \\
\hline $3,058.31$ & $1,348.59$ & 96.22 & 93.93 & 5.66 & 91.17 & 0.18 & 0.06 & 99.91 & 117.77 & 20.78 & 84.97 & 95.568 & 5.953 & 0.062 & 95.198 \\
\hline $3,058.31$ & $1,348.59$ & 97.37 & 93.93 & 5.66 & 98.78 & 0.18 & 0.06 & 94.48 & 117.77 & 20.78 & 103.5 & 98.673 & 4.159 & 0.042 & 98.498 \\
\hline $3,058.31$ & $1,348.59$ & 92.84 & 93.93 & 5.66 & 99.64 & 0.18 & 0.06 & 91.14 & 117.77 & 20.78 & 102.49 & 99.33 & 5.908 & 0.059 & 98.979 \\
\hline $3,058.31$ & $1,348.59$ & 102.48 & 93.93 & 5.66 & 86.5 & 0.18 & 0.06 & 96.22 & 117.77 & 20.78 & 76.79 & 93.232 & 8.85 & 0.095 & 92.392 \\
\hline $3,058.31$ & $1,348.59$ & 92.73 & 93.93 & 5.66 & 107.17 & 0.18 & 0.06 & 92.69 & 117.77 & 20.78 & 112.5 & 101.182 & 8.253 & 0.082 & 100.508 \\
\hline $3,058.31$ & $1,348.59$ & 94.17 & 93.93 & 5.66 & 96.41 & 0.18 & 0.06 & 98.57 & 117.77 & 20.78 & 105.52 & 96.33 & 5.538 & 0.057 & 96.012 \\
\hline $3,058.31$ & $1,348.59$ & 88.82 & 93.93 & 5.66 & 88.5 & 0.18 & 0.06 & 93.65 & 117.77 & 20.78 & 108.94 & 94.482 & 7.064 & 0.075 & 93.954 \\
\hline $3,058.31$ & $1,348.59$ & 116.1 & 93.93 & 5.66 & 105.26 & 0.18 & 0.06 & 113.94 & 117.77 & 20.78 & 81.94 & 106.543 & 11.585 & 0.109 & 105.284 \\
\hline $3,058.31$ & $1,348.59$ & 95.88 & 93.93 & 5.66 & 84.58 & 0.18 & 0.06 & 94.45 & 117.77 & 20.78 & 93.59 & 92.002 & 5.231 & 0.057 & 91.704 \\
\hline $3,058.31$ & $1,348.59$ & 103.11 & 93.93 & 5.66 & 110.28 & 0.18 & 0.06 & 109.71 & 117.77 & 20.78 & 107.45 & 104.235 & 5.559 & 0.053 & 103.939 \\
\hline $3,058.31$ & $1,348.59$ & 101.68 & 93.93 & 5.66 & 95.85 & 0.18 & 0.06 & 101.58 & 117.77 & 20.78 & 86.37 & 97.337 & 5.291 & 0.054 & 97.049 \\
\hline $3,058.31$ & $1,348.59$ & 95.03 & 93.93 & 5.66 & 102.68 & 0.18 & 0.06 & 96.71 & 117.77 & 20.78 & 105.04 & 102.008 & 5.427 & 0.053 & 101.72 \\
\hline $3,058.31$ & $1,348.59$ & 91.21 & 93.93 & 5.66 & 90.48 & 0.18 & 0.06 & 89.27 & 117.77 & 20.78 & 106.97 & 91.297 & 7.561 & 0.083 & 90.67 \\
\hline $3,058.31$ & $1,348.59$ & 89.39 & 93.93 & 5.66 & 90.25 & 0.18 & 0.06 & 91.97 & 117.77 & 20.78 & 109.37 & 92.637 & 7.71 & 0.083 & 91.995 \\
\hline $3,058.31$ & $1,348.59$ & 106.31 & 93.93 & 5.66 & 114.78 & 0.18 & 0.06 & 103.75 & 117.77 & 20.78 & 100.18 & 104.955 & 5.608 & 0.053 & 104.655 \\
\hline $3,058.31$ & $1,348.59$ & 101.22 & 93.93 & 5.66 & 111.67 & 0.18 & 0.06 & 97.48 & 117.77 & 20.78 & 108.51 & 106.133 & 5.036 & 0.047 & 105.894 \\
\hline
\end{tabular}




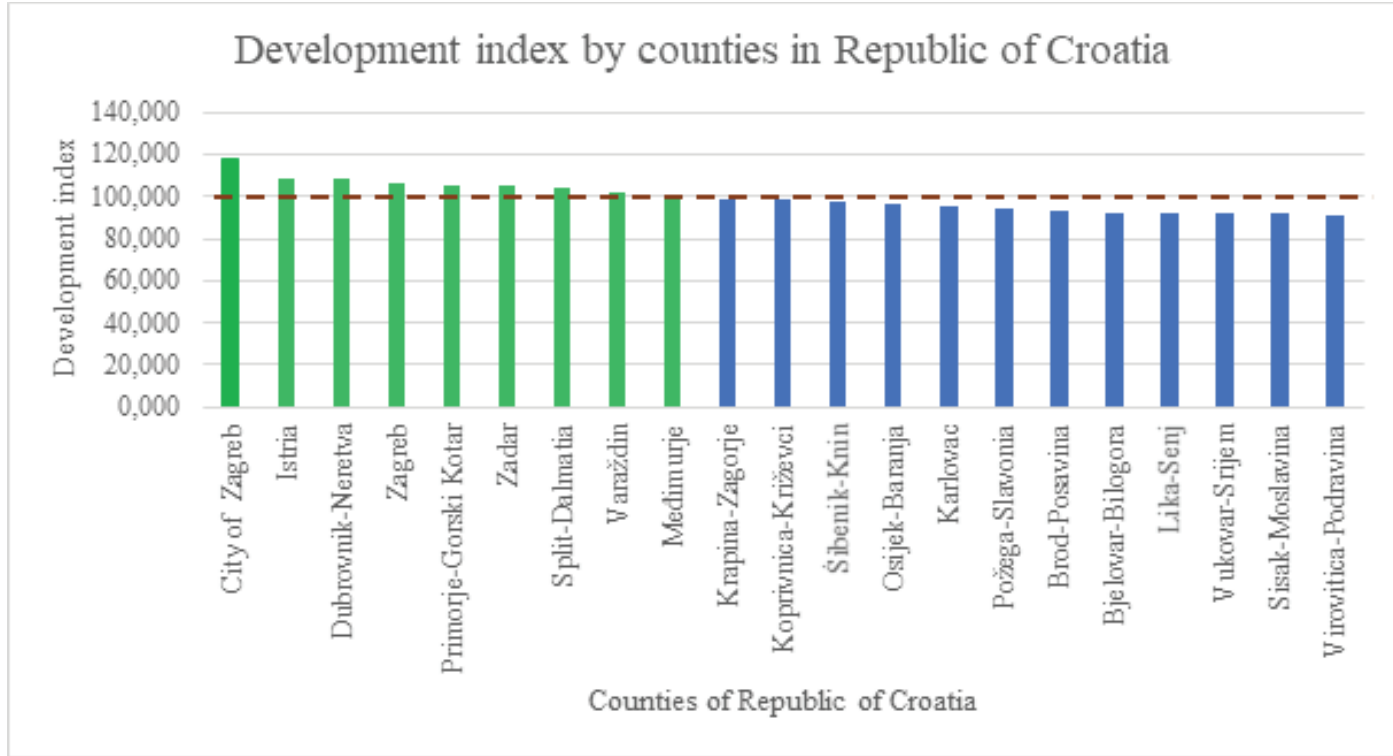

Developed counties

Undeveloped counties

Threshold

Figure 1.

Regional development index by counties of the Republic of Croatia in 2016.t

\section{THE INFLUENCE OF DRY PORT ESTABLISHMENT ON REGIONAL DEVELOPMENT AND INCREASE OF REGIONAL DEVELOPMENT INDEX - ANALYSIS AND RESULTS}

\subsection{Determining the Decrease/Increase Coefficients of Basic Indicators of the Regional Development Index}

As previously mentioned, the values of 6 basic indicators have an effect on development index increase:

1. unemployment rate,

2. income per capita,

3. budget revenues per capita,

4. general population movement,

5. education rate,

6. ageing index.

The basic indicators are obtained using ratios of variables, i.e. data taken from the Croatian Employment Service, the Croatian Tax Administration, the Ministry of Finance and the Croatian Bureau of Statistics.

Dry port establishment can affect a maximum of 4 basic indicators. General population movement and the ageing index are not expected to be affected by the establishment of a dry port.
Establishment of a dry port affects the following basic indicators: unemployment rate, income per capita, budget revenues per capita and education rate. The following text explains (in mathematical equations) the impact of dry port establishment on the basic development index indicators.

Unemployment rate is calculated using the following equation:

$x_{1}=\frac{N_{(0)}}{R S_{(0)}}=\frac{N_{(0)}}{Z_{(0)}+N_{(0)}}$

where variables are:

$N_{(0)}$ - the number of the unemployed in the area of a given local or regional self-government unit,

$R S_{(0)}$ - the sum of all employed and unemployed persons on the territory of a given local or regional self-government unit.

Therefore, if the number of the unemployed on the territory of a given local or regional self-government unit decreases due to the establishment of a new dry port terminal, i.e. due to new job vacancies at the dry port terminal, the equation for the new unemployment rate will be as follows: 
$x_{1}^{\prime}=\frac{N_{(0)}-p_{1}}{R S_{(0)}}=\frac{N_{(0)}-p_{1}}{Z_{(0)}+p_{1}+N_{(0)}-p_{1}}=\frac{N_{(0)}-p_{1}}{R S_{(0)}}$

where variables are:

$x_{1}{ }^{\prime}-$ new value of the basic indicator,

$p_{1}$ - number of newly employed persons.

Note. Although the value of variable $p_{1}$ is determined arbitrarily, it is the value closest to the possible actual value in the scenario of dry port establishment.

The unemployment rate decrease coefficient can then be illustrated as follows:

$k_{1}=\frac{x_{1}^{\prime}}{x_{1}}=\frac{\frac{N_{(0)}-p_{1}}{R S_{(0)}}}{\frac{N_{(0)}}{R S_{(0)}}}=\frac{N_{(0)}-p_{1}}{N_{(0)}}=1-\frac{p_{1}}{N_{(0)}}$

where:

$k_{1}$ - the unemployment rate decrease coefficient. equation:

Income per capita is calculated using the following

$x_{2}=\frac{D_{i}}{P_{i}}$

where variables are:

$D_{i}$ - the sum of incomes earned by residents in the i-th local or regional self-government unit during one calendar year,

$P_{i}$ - the estimated number of residents in the i-th local or regional self-government unit at the end of the year.

Therefore, if the number of the unemployed in a given local or regional self-government unit decreases owing to the establishment of a new dry port terminal through the creation of new jobs and new employees earning income, the equation will then be as follows:

$x_{2}^{\prime}=\frac{D_{i}+p_{2}}{P_{1}}$

where variables are:

$$
x_{2}{ }^{\prime}-\text { new value of the basic indicator, }
$$

$p_{2}$ - the amount of new income per capita depending on the number of newly employed persons.

Note. Value of variable $p 2$ is determined by multiplying the average yearly income per capita with arbitrarily determined number of newly employed persons ( $p 1)$. Average yearly income per capita is calculated by multiplying the average monthly income per capita (in Republic of Croatia) with twelve months.

The income percapita increase coefficient can then be shown as follows:

$$
k_{2}=\frac{x_{2}{ }^{\prime}}{x_{2}}=\frac{\frac{D_{i}+p_{2}}{P_{i}}}{\frac{D_{i}}{P_{i}}}=\frac{D_{i}+p_{2}}{D_{i}}=1+\frac{p_{2}}{D_{i}}
$$

where:

$k_{2}$ - is the income per capita increase coefficient.

Budget revenue per capita is calculated using the following equation:

$x_{3}=\frac{I P P_{i}}{P_{i}}$

where variables are:

$I P P_{i}$ - the amount of budget revenues generated on the territory of the i-th local or regional self-government unit during one calendar year,

$P_{i}$ - the estimate of the number of residents in the i-th local or regional self-government unit at the end of the year.

Therefore, if the number of the unemployed in a given local or regional self-government unit decreases owing to the establishment of a new dry port terminal through the creation of new jobs and new employees earning income, resulting in the employer paying taxes for them, budget revenues will increase, and the equation will then be as follows:

$x_{3}^{\prime}=\frac{I P P_{i}+P_{i}}{P_{i}}$

where variables are:

$x_{3}{ }^{\prime}-$ new value of the basic indicator,

$p_{3}$ - the amount of new budget revenue per capita depending on the number of newly employed persons. 
Note. Value of variable $p 3$ is determined by multiplying the average yearly budget revenues per capita with arbitrarily determined number of newly employed persons ( 1 1). Average yearly budget revenue per capita is calculated by multiplying average monthly budget revenue per capita (in Republic of Croatia) with twelve months.

The budget revenues per capita increase coefficient can then be shown as follows:

$$
k_{3}=\frac{x_{3}{ }^{\prime}}{x_{3}}=\frac{\frac{I P P_{i}+p_{3}}{P_{i}}}{\frac{I P P_{i}}{P_{i}}}=\frac{I P P_{i}+p_{3}}{I P P_{i}}=1+\frac{p_{3}}{I P P_{i}}
$$

where:

$k_{3}$ - budget revenues per capita increase coefficient.

The education rate is calculated using the following equation:

$x_{5}=\frac{P_{(\text {he+ })}}{P_{(20+)}}$

where variables are:

$P_{(\text {he+) }}$ - the number of residents in the i-th local or regional self-government unit with completed higher education,

$P_{(20+)}$ - the number of residents in the i-th local or regional self-government unit aged 20-65.

Therefore, if the establishment of a new dry port terminal creates new jobs, the need for highly educated staff will also increase, in turn encouraging more people to acquire higher education at higher education institutions, and the equation will then be as follows:

$x_{5}{ }^{\prime}=\frac{P_{(\text {he+ })}+P_{5}}{P_{(20+)}}$

where variables are:

$x_{5}{ }^{\prime}-$ new value of the basic indicator,

$p_{5}$ - number of new highly educated persons.

Note. Although the value of variable $p 5$ is determined arbitrarily, it is the value closest to the possible actual value in the scenario of dry port establishment.
The education rate increase coefficient can then be shown as follows:

$k_{5}=\frac{x_{5}^{\prime}}{x_{5}}=\frac{\frac{P_{(\text {het })}+p_{5}}{P_{(20+)}}}{\frac{P_{(h e+)}}{P_{(20+)}}}=\frac{P_{(\text {het })}+p_{5}}{P_{(\text {het })}}=1+\frac{P_{5}}{P_{(\text {het })}}$

where:

$k_{5}$ - the education rate increase coefficient.

\subsection{Simulation and Results of Regional Development Index Increase by Dry Port Establishment}

The value of $\mathrm{p} 1$ was arbitrarily chosen based on the previous section 7.1, where variables $p 1, p 2, p 3$, and $p 5$ were defined, while p2, p3, and p5 were calculated as explained in 7.1. Variables p1, p2, p3, and p5 are the values that would change (add or subtract) in the basic indicators values in case of dry port establishment, i.e. following the application of their values, the new values of basic indicators would be obtained for the Vukovar-Srijem county/ region, as well as the new values of mean average and standard deviation for all counties of the Republic of Croatia in the observed case.

A simulation of development index increase by dry port establishment was run (Table 3 ) by simulating the scenario of dry port establishment in the town of Vinkovci in the VukovarSrijem County. The increase is primarily attributable to the increased number of newly employed persons due to dry port establishment. Vinkovci was chosen primarily owing to its favourable geographic position in the TEN-T network connecting Croatia with various destinations through the Orient East-Med Corridor or Rhine-Danube Corridor, existing infrastructure that can be used for new dry port terminal, and the fact that VukovarSrijem is one of the most undeveloped regions (counties) in Croatia. The simulation calculated the development index for each county of the Republic of Croatia, using statistical data taken from the Croatian Employment Service, the Croatian Tax Administration, the Ministry of Finance and the Croatian Bureau of Statistics for year 2016, and the calculated number of persons employed in the new dry port (as if the dry port was established), their incomes, budget revenues, and estimated education rate. The results, i.e. new values of the development index were obtained. The development index of the Vukovar-Srijem county was 92,175 (Table 3), whereas the development index in case of non-establishment of a dry port was 91,995 (Table 2), which proves the influence of dry port establishment on regional development. 
Table 3.

Simulation of development index increase by dry port establishment - new calculation of the development index.

\begin{tabular}{|c|c|c|c|c|c|c|c|c|c|c|c|c|}
\hline \multirow[t]{3}{*}{ County } & \multicolumn{12}{|c|}{ Parameters for calculating the value of basic indicators for the county (including established dry port in Vinkovci) } \\
\hline & \multicolumn{4}{|l|}{$\mathbf{x} 1$} & \multicolumn{4}{|l|}{$\mathbf{x} 2$} & \multicolumn{4}{|l|}{ x3 } \\
\hline & $\begin{array}{l}\mathrm{N}(0) \\
(2016)\end{array}$ & $\mathrm{N}(0)^{\prime}$ & $\mathrm{RS}(0)$ & p1 & Di & Di' & $\mathrm{Pi}(2016)$ & p2 & $\mathrm{IPPi}$ & IPPi' & $\mathrm{Pi}(2016)$ & p3 \\
\hline Bjelovar-Bilogora & 9,789 & 0 & 43,584 & 0 & $2,632,167,864$ & 0 & 111,867 & 0 & $213,957,943$ & 0 & 111,867 & 0 \\
\hline Brod-Posavina & 12,471 & 0 & 58,194 & 0 & $3,279,929,087$ & 0 & 148,373 & 0 & $230,113,169$ & 0 & 148,373 & 0 \\
\hline Dubrovnik-Neretva & 9,714 & 0 & 73,424 & 0 & $3,769,453,577$ & 0 & 121,970 & 0 & $591,386,181$ & 0 & 121,970 & 0 \\
\hline City of Zagreb & 36,636 & 0 & 363,813 & 0 & $35,891,154,245$ & 0 & 802,338 & 0 & $5,000,563,562$ & 0 & 802,338 & 0 \\
\hline Istria & 12,142 & 0 & 185,657 & 0 & $7,323,458,433$ & 0 & 208,105 & 0 & $1,151,992,281$ & 0 & 208,105 & 0 \\
\hline Karlovac & 7,122 & 0 & 41,215 & 0 & $3,575,378,221$ & 0 & 120,321 & 0 & $306,488,870$ & 0 & 120,321 & 0 \\
\hline Koprivnica-Križevci & 7,244 & 0 & 52,876 & 0 & $2,728,672,339$ & 0 & 110,976 & 0 & $299,999,201$ & 0 & 110,976 & 0 \\
\hline Krapina-Zagorje & 6,533 & 0 & 57,559 & 0 & $3,677,032,003$ & 0 & 127,748 & 0 & $267,270,533$ & 0 & 127,748 & 0 \\
\hline Lika-Senj & 3,413 & 0 & 20,124 & 0 & $1,284,790,279$ & 0 & 46,888 & 0 & $159,057,694$ & 0 & 46,888 & 0 \\
\hline Međimurje & 6,415 & 0 & 55,112 & 0 & $2,783,758,337$ & 0 & 112,089 & 0 & $232,817,820$ & 0 & 112,089 & 0 \\
\hline Osijek-Baranja & 25,525 & 0 & 107,746 & 0 & $7,613,513,595$ & 0 & 290,412 & 0 & $659,743,461$ & 0 & 290,412 & 0 \\
\hline Požega-Slavonia & 5,803 & 0 & 31,990 & 0 & $1,648,782,542$ & 0 & 71,920 & 0 & $111,493,980$ & 0 & 71,920 & 0 \\
\hline Primorje-Gorski Kotar & 16,919 & 0 & 148,282 & 0 & $10,238,122,479$ & 0 & 289,479 & 0 & $1,513,685,691$ & 0 & 289,479 & 0 \\
\hline Sisak-Moslavina & 12,968 & 0 & 52,694 & 0 & $4,275,502,341$ & 0 & 157,204 & 0 & $393,351,133$ & 0 & 157,204 & 0 \\
\hline Split-Dalmatia & 37,089 & 0 & 192,871 & 0 & $12,742,920,894$ & 0 & 452,035 & 0 & $1,571,531,320$ & 0 & 452,035 & 0 \\
\hline Šibenik-Knin & 9,054 & 0 & 55,820 & 0 & $2,814,048,491$ & 0 & 103,021 & 0 & $338,310,662$ & 0 & 103,021 & 0 \\
\hline Varaždin & 8,955 & 0 & 91,940 & 0 & $4,897,667,082$ & 0 & 170,563 & 0 & $407,176,522$ & 0 & 170,563 & 0 \\
\hline Virovitica-Podravina & 7,513 & 0 & 28,752 & 0 & $1,684,849,909$ & 0 & 79,111 & 0 & $148,121,108$ & 0 & 79,111 & 0 \\
\hline Vukovar-Srijem & 15,819 & 15,569 & 65,072 & 250 & $3,690,107,101$ & $3,708,837,474$ & 165,799 & $18,730,372$ & $269,804,713$ & $271,174,197$ & 165,799 & $1,369,484$ \\
\hline Zadar & 11,327 & 0 & 94,392 & 0 & $4,515,967,467$ & 0 & 169,581 & 0 & $662,871,779$ & 0 & 169,581 & 0 \\
\hline \multirow[t]{2}{*}{ Zagreb } & 15,045 & 0 & 139,435 & 0 & $10,247,764,217$ & 0 & 314,549 & 0 & $1,013,741,099$ & 0 & 314,549 & 0 \\
\hline & CES & & Tax adm, & & Tax adm, & & CBS & & Min, of Fin, & & CBS & \\
\hline
\end{tabular}




\begin{tabular}{|c|c|c|c|c|c|c|c|c|c|c|c|c|c|c|c|}
\hline \multirow[b]{2}{*}{ x5 } & & & & \multicolumn{6}{|c|}{ Values of new standardized indicators for the county } & \multicolumn{6}{|c|}{ Values of new standardized indicators for the county } \\
\hline & & & & \multirow[t]{2}{*}{$\mathbf{x} 11^{\prime}$} & \multirow[t]{2}{*}{$\mathbf{x 2}$} & \multirow[t]{2}{*}{$\mathbf{x} 3^{\prime}$} & \multirow[t]{2}{*}{$\mathbf{x 4}$} & \multirow[t]{2}{*}{$\mathbf{x} 5^{\prime}$} & \multirow[t]{2}{*}{ x6 } & \multicolumn{3}{|l|}{$\mathbf{x} 1$} & \multicolumn{3}{|l|}{$\mathbf{x 2}$} \\
\hline Phe+ (2011) & Phe+' & P20+ & p5 & & & & & & & Mxj & Sxj & $\mathrm{x} 1$ & Mxj & Sxj & $x 2$ \\
\hline 9.426 & 0 & 71,954 & 0 & 0.2246 & $23,529.44$ & $1,912.61$ & 89.02 & 0.131 & 114.9 & 0.1622 & 0.0564 & 88.94 & $28,123.34$ & $5,365.14$ & 91.44 \\
\hline 12.455 & 0 & 92,809 & 0 & 0.2143 & $22,105.97$ & $1,550.91$ & 90.09 & 0.1342 & 96.5 & 0.1622 & 0.0564 & 90.76 & $28,123.34$ & $5,365.14$ & 88.79 \\
\hline 19.221 & 0 & 73,419 & 0 & 0.1323 & $30,904.76$ & $4,848.62$ & 101.07 & 0.2618 & 109.4 & 0.1622 & 0.0564 & 105.3 & $28,123.34$ & $5,365.14$ & 105.19 \\
\hline 195.326 & 0 & 496,381 & 0 & 0.1007 & $44,733.21$ & $6,232.49$ & 103.1 & 0.3935 & 118.9 & 0.1622 & 0.0564 & 110.9 & $28,123.34$ & $5,365.14$ & 130.96 \\
\hline 29.874 & 0 & 132,773 & 0 & 0.0654 & $35,191.17$ & $5,535.63$ & 101.17 & 0.225 & 136.8 & 0.1622 & 0.0564 & 117.16 & $28,123.34$ & $5,365.14$ & 113.18 \\
\hline 14.332 & 0 & 78,061 & 0 & 0.1728 & $29,715.33$ & $2,547.26$ & 88.93 & 0.1836 & 149 & 0.1622 & 0.0564 & 98.12 & $28,123.34$ & $5,365.14$ & 102.97 \\
\hline 10.404 & 0 & 70,155 & 0 & 0.137 & $24,587.95$ & $2,703.28$ & 93.24 & 0.1483 & 110.5 & 0.1622 & 0.0564 & 104.47 & $28,123.34$ & $5,365.14$ & 93.42 \\
\hline 10.352 & 0 & 81,769 & 0 & 0.1135 & $28,783.48$ & $2,092.17$ & 93.73 & 0.1266 & 112.6 & 0.1622 & 0.0564 & 108.63 & $28,123.34$ & $5,365.14$ & 101.24 \\
\hline 4.605 & 0 & 28,853 & 0 & 0.1696 & $27,401.26$ & $3,392.29$ & 86.29 & 0.1596 & 166 & 0.1622 & 0.0564 & 98.69 & $28,123.34$ & $5,365.14$ & 98.66 \\
\hline 9.547 & 0 & 69,839 & 0 & 0.1164 & $24,835.25$ & $2,077.08$ & 97.99 & 0.1367 & 91.8 & 0.1622 & 0.0564 & 108.12 & $28,123.34$ & $5,365.14$ & 93.88 \\
\hline 32.878 & 0 & 187,982 & 0 & 0.2369 & $26,216.25$ & $2,271.75$ & 91.9 & 0.1749 & 106.3 & 0.1622 & 0.0564 & 86.76 & $28,123.34$ & $5,365.14$ & 96.45 \\
\hline 6.498 & 0 & 45,472 & 0 & 0.1814 & $22,925.23$ & $1,550.25$ & 87.42 & 0.1429 & 99.2 & 0.1622 & 0.0564 & 96.6 & $28,123.34$ & $5,365.14$ & 90.32 \\
\hline 52.036 & 0 & 189,428 & 0 & 0.1141 & $35,367.41$ & $5 ., 229.00$ & 96.91 & 0.2747 & 155.3 & 0.1622 & 0.0564 & 108.53 & $28,123.34$ & $5,365.14$ & 113.51 \\
\hline 15.446 & 0 & 104,294 & 0 & 0.2461 & $27,197.16$ & $2,502.17$ & 85.2 & 0.1481 & 131.1 & 0.1622 & 0.0564 & 85.13 & $28,123.34$ & $5,365.14$ & 98.28 \\
\hline 68.450 & 0 & 276,901 & 0 & 0.1923 & $28,190.12$ & $3,476.57$ & 99.75 & 0.2472 & 102.3 & 0.1622 & 0.0564 & 94.66 & $28,123.34$ & $5,365.14$ & 100.13 \\
\hline 12.405 & 0 & 63,812 & 0 & 0.1622 & $27,315.29$ & $3,283.90$ & 91.58 & 0.1944 & 146.1 & 0.1622 & 0.0564 & 100 & $28,123.34$ & $5,365.14$ & 98.5 \\
\hline 17.742 & 0 & 108,980 & 0 & 0.0974 & $28,714.71$ & $2,387.25$ & 95.45 & 0.1628 & 107.3 & 0.1622 & 0.0564 & 111.49 & $28,123.34$ & $5,365.14$ & 101.11 \\
\hline 5.882 & 0 & 51,371 & 0 & 0.2613 & $21,297.29$ & $1,872.32$ & 88.54 & 0.1145 & 103.3 & 0.1622 & 0.0564 & 82.43 & $28,123.34$ & $5,365.14$ & 87.28 \\
\hline 14.089 & 14.189 & 106,735 & 100 & 0.2393 & $22,369.48$ & $1,635.56$ & 88.41 & 0.1329 & 98.3 & 0.1622 & 0.0564 & 86.34 & $28,123.34$ & $5,365.14$ & 89.28 \\
\hline 21.179 & 0 & 101,578 & 0 & 0.12 & $26,630.15$ & $3,908.88$ & 102.3 & 0.2085 & 117.4 & 0.1622 & 0.0564 & 107.48 & $28,123.34$ & $5,365.14$ & 97.22 \\
\hline 33.086 & 0 & 197,175 & 0 & 0.1079 & $32,579.23$ & $3,222.84$ & 100.54 & 0.1678 & 100.1 & 0.1622 & 0.0564 & 109.62 & $28,123.34$ & $5,365.14$ & 108.31 \\
\hline CBS & & CBS & & & & & & & & & & & & & \\
\hline
\end{tabular}




\begin{tabular}{|c|c|c|c|c|c|c|c|c|c|c|c|c|c|c|c|}
\hline \multicolumn{12}{|c|}{ Values of new standardized indicators for the county } & \multicolumn{4}{|c|}{ Regional (County) Development Index } \\
\hline $\mathbf{x} 3$ & & & $\mathbf{x 4}$ & & & $\mathbf{x} 5$ & & & $\mathrm{x} 6$ & & & Mzi & Szi & cvi & li' \\
\hline Mxj & Sxj & $x 3$ & Mxj & Sxj & $\mathrm{x} 4$ & Mxj & Sxj & $x 5$ & Mxj & Sxj & $x 6$ & & & & \\
\hline $3,058.71$ & $1,348.18$ & 91.5 & 93.9348 & 5.6622 & 91.33 & 0.1842 & 0.0649 & 91.8 & 117.7667 & 20.7761 & 101.38 & 92.732 & 3.983 & 0.043 & 92.561 \\
\hline $3,058.71$ & $1,348.18$ & 88.82 & 93.9348 & 5.6622 & 93.21 & 0.1842 & 0.0649 & 92.29 & 117.7667 & 20.7761 & 110.24 & 94.018 & 7.436 & 0.079 & 93.43 \\
\hline $3,058.71$ & $1,348.18$ & 113.28 & 93.9348 & 5.6622 & 112.61 & 0.1842 & 0.0649 & 111.96 & 117.7667 & 20.7761 & 104.03 & 108.728 & 3.928 & 0.036 & 108.586 \\
\hline $3,058.71$ & $1,348.18$ & 123.55 & 93.9348 & 5.6622 & 116.19 & 0.1842 & 0.0649 & 132.25 & 117.7667 & 20.7761 & 99.46 & 118.885 & 11.508 & 0.097 & 117.771 \\
\hline $3,058.71$ & $1,348.18$ & 118.38 & 93.9348 & 5.6622 & 112.78 & 0.1842 & 0.0649 & 106.29 & 117.7667 & 20.7761 & 90.84 & 109.772 & 9.308 & 0.085 & 108.982 \\
\hline $3,058.71$ & $1,348.18$ & 96.21 & 93.9348 & 5.6622 & 91.17 & 0.1842 & 0.0649 & 99.91 & 117.7667 & 20.7761 & 84.97 & 95.558 & 5.947 & 0.062 & 95.188 \\
\hline $3,058.71$ & $1,348.18$ & 97.37 & 93.9348 & 5.6622 & 98.78 & 0.1842 & 0.0649 & 94.47 & 117.7667 & 20.7761 & 103.5 & 98.668 & 4.161 & 0.042 & 98.493 \\
\hline $3,058.71$ & $1,348.18$ & 92.84 & 93.9348 & 5.6622 & 99.64 & 0.1842 & 0.0649 & 91.12 & 117.7667 & 20.7761 & 102.49 & 99.327 & 5.912 & 0.06 & 98.975 \\
\hline $3,058.71$ & $1,348.18$ & 102.48 & 93.9348 & 5.6622 & 86.5 & 0.1842 & 0.0649 & 96.21 & 117.7667 & 20.7761 & 76.79 & 93.222 & 8.844 & 0.095 & 92.383 \\
\hline $3,058.71$ & $1,348.18$ & 92.72 & 93.9348 & 5.6622 & 107.17 & 0.1842 & 0.0649 & 92.68 & 117.7667 & 20.7761 & 112.5 & 101.178 & 8.259 & 0.082 & 100.504 \\
\hline $3,058.71$ & $1,348.18$ & 94.17 & 93.9348 & 5.6622 & 96.41 & 0.1842 & 0.0649 & 98.57 & 117.7667 & 20.7761 & 105.52 & 96.313 & 5.564 & 0.058 & 95.992 \\
\hline $3,058.71$ & $1,348.18$ & 88.82 & 93.9348 & 5.6622 & 88.5 & 0.1842 & 0.0649 & 93.64 & 117.7667 & 20.7761 & 108.94 & 94.47 & 7.064 & 0.075 & 93.942 \\
\hline $3,058.71$ & $1,348.18$ & 116.1 & 93.9348 & 5.6622 & 105.26 & 0.1842 & 0.0649 & 113.94 & 117.7667 & 20.7761 & 81.94 & 106.547 & 11.587 & 0.109 & 105.287 \\
\hline $3,058.71$ & $1,348.18$ & 95.88 & 93.9348 & 5.6622 & 84.58 & 0.1842 & 0.0649 & 94.44 & 117.7667 & 20.7761 & 93.59 & 91.983 & 5.248 & 0.057 & 91.684 \\
\hline $3,058.71$ & $1,348.18$ & 103.1 & 93.9348 & 5.6622 & 110.28 & 0.1842 & 0.0649 & 109.71 & 117.7667 & 20.7761 & 107.45 & 104.222 & 5.578 & 0.054 & 103.923 \\
\hline $3,058.71$ & $1,348.18$ & 101.68 & 93.9348 & 5.6622 & 95.85 & 0.1842 & 0.0649 & 101.57 & 117.7667 & 20.7761 & 86.37 & 97.328 & 5.287 & 0.054 & 97.041 \\
\hline $3,058.71$ & $1,348.18$ & 95.02 & 93.9348 & 5.6622 & 102.68 & 0.1842 & 0.0649 & 96.7 & 117.7667 & 20.7761 & 105.04 & 102.007 & 5.437 & 0.053 & 101.717 \\
\hline $3,058.71$ & $1,348.18$ & 91.21 & 93.9348 & 5.6622 & 90.48 & 0.1842 & 0.0649 & 89.26 & 117.7667 & 20.7761 & 106.97 & 91.272 & 7.585 & 0.083 & 90.641 \\
\hline $3,058.71$ & $1,348.18$ & 89.45 & 93.9348 & 5.6622 & 90.25 & 0.1842 & 0.0649 & 92.1 & 117.7667 & 20.7761 & 109.37 & 92.798 & 7.604 & 0.082 & 92.175 \\
\hline $3,058.71$ & $1,348.18$ & 106.31 & 93.9348 & 5.6622 & 114.78 & 0.1842 & 0.0649 & 103.74 & 117.7667 & 20.7761 & 100.18 & 104.952 & 5.61 & 0.053 & 104.652 \\
\hline $3,058.71$ & $1,348.18$ & 101.22 & 93.9348 & 5.6622 & 111.67 & 0.1842 & 0.0649 & 97.47 & 117.7667 & 20.7761 & 108.51 & 106.133 & 5.04 & 0.047 & 105.894 \\
\hline
\end{tabular}




\section{DISCUSSION}

Based on existing literature on regional development, the dry port concept and the influence of dry ports on regional development, the authors found a correlation between regional development factors and dry port establishment.

The regional development index calculation method is based on six basic indicators. The parameters required to calculate the six basic indicators are explained earlier in this paper. The hypothesis was that dry port establishment would affect the unemployment rate, as one of the basic indicators for the calculation of the regional development index. Consequently, the number of newly employed persons affects other three basic indicators for the calculation of the regional development index: income per capita, budget revenues per capita and education rate.

The influence of dry port establishment was illustrated by introducing new variables related to newly employed persons and running simulations for both the current scenario, without a dry port, and scenario in case of dry port establishment.

The results show a conclusive increase in regional development index due to dry port establishment.

The result is significant as it conclusively proves that a dry port would increase the regional development index, by observing solely its influence on the unemployment rate (and consequently parameters such as income per capita, budget revenue per capita and education rate). If the number of employed persons was higher, or other factors were included and analyzed, the increase in the regional development index would be greater, which is the area for further research.

\section{CONCLUSIONS}

After defining the concept of dry port and its importance for regional development, the method of calculation of the development index of a region was defined and explained. Using statistical data, an example of the calculation of the development index by regions/ counties in the Republic of Croatia in the current scenario without an established dry port, was provided. After that, a simulation of development index calculation was made that included data in case of dry port establishment in the Vukovar-Srijem County, in the town of Vinkovci. Simulation results have shown that the development index of the VukovarSrijem County would increase compared to the current situation without a dry port, proving the effect of dry port establishment on the development of the region/ county. Only factors influenced by the establishment of the dry port were included in the simulation. Although the results suggest that the development index would increase by approximately $1 \%$ in comparison with the current scenario, that percentage would actually be higher as dry port establishment would attract new operators/ companies into the region, who would cooperate with the dry port and open further new jobs and thus directly influence the development index, which shall be the subject of future research.

Source of research support: Institute of Traffic and Communications

\section{REFERENCES}

Agallos, I-C.D., 2016. The Contribution of Ports in Regional Development: Comparative Estimates via Indicator of Port Sustainability, Master of Science Thesis, Athens University of Economics and Business. Available at: https://doi.org/10.13140/RG.2.2.20796.44167.

Amendment of Regional Development Act of the Republic of Croatia, 2017. Official Gazette 2017(123)

Bask, A. et al., 2014. Development of seaport-dry port dyads: two cases from Northern Europe. Journal of Transport Geography, 39, pp.85-95. Available at: http://dx.doi.org/10.1016/j.jtrangeo.2014.06.014.

Black, J. et al., 2018. Issues in Dry Port Location and Implementation in Metropolitan Areas: The Case of Sydney, Australia. Transactions on Maritime Science, 7(1), pp.4150. Available at:

http://dx.doi.org/10.7225/toms.v07.n01.004.

Bogdan, S., Bareša, S. \& Hađina, V., 2019. Testiranje primjenjivosti Altmanovog Z-score modela za predviđanje stečaja u Republici Hrvatskoj. Notitia, 5(1), pp.31-46. Available at:

http://dx.doi.org/10.32676/n.5.1.4

Centar za lokalni ekonomski razvoj Ekonomskog fakulteta Sveučilišta u Rijeci, 2017. Evaluacija postojećeg i prijedlog novog modela za izračun indeksa te izračun novog indeksa razvijenosti jedinica lokalne i područne samouprave u Republici Hrvatskoj, available at: https://razvoj.gov.hr/UserDocsImages//O\%20ministarstvu/ Regionalni\%20razvoj/indeks\%20razvijenosti//Studija_novi\%20model\%20 indeksa\%20razvijenosti_CLER.pdf, accessed on: 12 August 2020.

Chandrakant, G. G., 2011. Essays on Dry Ports, Erasmus Universiteit Rotterdam, Mumbai, India. Available at: http://repub.eur.nl/res/pub/26877/, accessed on: 12 August 2020.

Crainic, T.G. et al., 2015. Modeling dry-port-based freight distribution planning. Transportation Research Part C: Emerging Technologies, 55, pp.518-534. Available at: http://dx.doi.org/10.1016/j.trc.2015.03.026.

Croatian Bureau of Statistics, 2011. Census of Population, Households and Dwellings 2011, Population According to Education Features. Available at: https://www.dzs.hr/ Hrv_Eng/publication/2016/SI-1582.pdf, accessed on: 12 August 2020.

Croatian Bureau of Statistics, 2016. Population Estimate of Republic of Croatia. Available at: https://www.dzs.hr/Hrv_Eng/publication/2017/07-01-03_01_2017. htm, accessed on: 12 August 2020.

Croatian Employment Service, 2016. Statistics On-line. Available at: https://statistika. hzz.hr/Statistika.aspx?tiplzvjestaja=1, accessed on: 12 August 2020.

De Muro, P., Mazziotta, M. \& Pareto, A., 2010. Composite Indices of Development and Poverty: An Application to MDGs. Social Indicators Research, 104(1), pp.1-18. Available at:

http://dx.doi.org/10.1007/s11205-010-9727-z.

Dorostkar, E., Shahbazi, S. and Naeini, S.A., 2016. The effect of forming dry port in spatial and regional planning system in Yazd Province, Journal of Engineering and Applied Sciences, 11(1), pp. 145-152. Available at: https://medwelljournals.com/abs tract/?doi=jeasci.2016.145.152. 
Dragović, B., Tzannatos, E. \& Park, N.K., 2016. Simulation modelling in ports and container terminals: literature overview and analysis by research field, application area and tool. Flexible Services and Manufacturing Journal, 29(1), pp.4-34. Available at: http://dx.doi.org/10.1007/s10696-016-9239-5.

FDT - Association of Danish Transport and Logistics Centers, 2011. The Dry Port - Concept and Perspectives. Available at: http://archive.northsearegion.eu/files/ repository/20130301142236_WPC-TheDryPortConcept.pdf, accessed on: 14 August 2020.

Flämig, H. \& Hesse, M., 2011. Placing dryports. Port regionalization as a planning challenge - The case of Hamburg, Germany, and the Süderelbe. Research in Transportation Economics, 33(1), pp.42-50. Available at: http://dx.doi.org/10.1016/j.retrec.2011.08.005.

Hanaoka, S. \& Regmi, M.B., 2011. Promoting intermodal freight transport through the development of dry ports in Asia: An environmental perspective. IATSS Research, 35(1), pp.16-23. Available at:

http://dx.doi.org/10.1016/j.iatssr.2011.06.001.

Jeevan, J. et al., 2019. A Procedure for Implementing Exploratory Mixed Methods Research into Dry Port Management. Transactions on Maritime Science, 8(2), pp.157-170. Available at:

http://dx.doi.org/10.7225/toms.v08.n02.001.

Khaslavskaya, A. \& Roso, V., 2020. Dry ports: research outcomes, trends, and future implications. Maritime Economics \& Logistics, 22(2), pp.265-292. Available at: http://dx.doi.org/10.1057/s41278-020-00152-9.

Li, J. and Jiang, B., 2014. Cooperation performance evaluation between seaport and dry port; case of Qingdao Port and Xi'an Port, International Journal of e-Navigation and Maritime Economy, 1, pp. 99-109. Available at:

https://doi.org/10.1016/j.enavi.2014.12.009.

Mazziotta, M. \& Pareto, A., 2015. On a Generalized Non-compensatory Composite Index for Measuring Socio-economic Phenomena. Social Indicators Research, 127(3), pp.983-1003. Available at: http://dx.doi.org/10.1007/s11205-015-0998-2.

Ministry of Regional Development and EU Funds, 2018. Development Index. Available at: https://razvoj.gov.hr/o-ministarstvu/djelokrug-1939/regionalni-razvoj/ indeks-razvijenosti/112, accessed on:12 August 2020.

Ng, A.K. and Tongzon, J.L., 2010. The transportation sector of India's economy: Dry ports as catalysts for regional development, Eurasian Geography and Economics, 51(5), pp. 669-682. Available at:

https://doi.org/10.2747/1539-7216.51.5.669.

Ng, A.K.Y. \& Cetin, I.B., 2012. Locational Characteristics of Dry Ports in Developing Economies: Some Lessons from Northern India. Regional Studies, 46(6), pp.757-773. Available at:

http://dx.doi.org/10.1080/00343404.2010.532117.

Ng, A.Y. \& Gujar, G.C., 2009. Government policies, efficiency and competitiveness: The case of dry ports in India. Transport Policy, 16(5), pp.232-239. Available at: http://dx.doi.org/10.1016/j.tranpol.2009.08.001.

Nguyen, L.C. \& Notteboom, T., 2018. The relations between dry port characteristics and regional port-hinterland settings: findings for a global sample of dry ports.
Maritime Policy \& Management, 46(1), pp.24-42. Available at: http://dx.doi.org/10.1080/03088839.2018.1448478.

Notteboom, T.E. \& Rodrigue, J.-P., 2005. Port regionalization: towards a new phase in port development. Maritime Policy \& Management, 32(3), pp.297-313. Available at: http://dx.doi.org/10.1080/03088830500139885.

Oláh, J. et al., 2018. Development of dry ports in Europe. International Journal of Applied Management Science, 10(4), p.269. Available at:

http://dx.doi.org/10.1504/ijams.2018.095330.

Regional Development Act of the Republic of Croatia, 2014. Official Gazette 2014(147)

Regulation on the Development Index, 2017. Official Gazette 2017(131).

Rodrigue, J.-P. \& Notteboom, T., 2010. Foreland-based regionalization: Integrating intermediate hubs with port hinterlands. Research in Transportation Economics, 27(1), pp.19-29. Available at:

http://dx.doi.org/10.1016/j.retrec.2009.12.004.

Rogić, K., Rožić, T. \& Kolarić, G., 2013. Functionality of logistics distribution centers as a inland port terminal (dry port terminals) - case study city of Zagreb, Conference of Planning and development of sustainable transport system, Zagreb, Croatia, April 16, pp. 83-95. Available at: https://www.researchgate.net/ publication/271836273_FUNKCIONALNOST_LOGISTICKO-DISTRIBUCIJSKIH_ CENTARA_KAO_LUCKIH_POZADINSKIH_TERMINALA_DRY_PORT_TERMINALA CASE_STUDY_CITY_OF_ZAGREB_FUNCTIONALITY_OF_LOGISTICS_DISTRIBUTION_ CENTERS_AS_A_INLAND_PORT_TERMIN, accessed on: 15 August 2020.

Roso, V., 2008. Factors influencing implementation of a dry port G. Kovacs, ed. International Journal of Physical Distribution \& Logistics Management, 38(10), pp.782-798. Available at: http://dx.doi.org/10.1108/09600030810926493.

Roso, V., 2013. Sustainable intermodal transport via dry ports - importance of directional development. World Review of Intermodal Transportation Research, 4(2/3), p.140. Available at: http://dx.doi.org/10.1504/writr.2013.058976.

Roso, V., Woxenius, J. \& Lumsden, K., 2009. The dry port concept: connecting container seaports with the hinterland. Journal of Transport Geography, 17(5), pp.338-345. Available at:

http://dx.doi.org/10.1016/j.jtrangeo.2008.10.008.

Shi, X. \& Li, H., 2016. Developing the port hinterland: Different perspectives and their application to Shenzhen Port, China. Research in Transportation Business \& Management, 19, pp.42-50. Available at:

http://dx.doi.org/10.1016/j.rtbm.2016.05.004.

Wang, G.W.Y. et al., 2016. Port connectivity in a logistic network: The case of Bohai Bay, China. Transportation Research Part E: Logistics and Transportation Review, 95, pp.341-354. Available at: http://dx.doi.org/10.1016/j.tre.2016.04.009.

Wilmsmeier, G., Monios, J. \& Lambert, B., 2011. The directional development of intermodal freight corridors in relation to inland terminals. Journal of Transport Geography, 19(6), pp.1379-1386. Available at: http://dx.doi.org/10.1016/j.jtrangeo.2011.07.010. 